\title{
PENERAPAN MODEL PEMBELAJARAN BERBASIS MASALAH UNTUK MENINGKATKAN AKTIVITAS DAN HASIL BELAJAR PESERTA DIDIK KELAS VIIG SMPN 10 KOTA BENGKULU
}

\author{
Bunga Yusmardi ${ }^{1 *}$, Irdam Idrus ${ }^{1}$, Abdul Rahman $^{1}$ \\ ${ }^{1}$ Program Studi Pendidikan Biologi, Fakultas Keguruan dan Ilmu Pendidikan, Universitas Bengkulu \\ Email: Bungayusmardi2@gmail.com
}

\begin{abstract}
Abstrak
Penelitian ini bertujuan untuk mendeskripsikan aktivitas dan hasil belajar peserta didik kelas $\mathrm{VII}_{\mathrm{G}}$ SMPN 10 Kota Bengkulu melalui penerapan model pembelajaran berbasis masalah pada materi Pencemaran Lingkungan. Jenis penelitian ini adalah penelitian tindakan kelas (PTK) dengan metode deskriptif. Penelitian ini terdiri dari dua siklus, setiap siklus terdiri atas empat tahap yaitu perencanaan, pelaksanaan, observasi, refleksi. Subyek penelitian adalah guru dan seluruh peserta didik kelas $\mathrm{VII}_{\mathrm{G}}$ SMPN 10 Kota Bengkulu tahun ajaran 2017/2018 yang berjumlah 32 orang. Instrumen penelitian yang digunakan adalah lembar observasi untuk mengetahui aktivitas guru dan peserta didik, sedangkan lembar tes digunakan untuk mengetahui hasil belajar peserta didik. Data hasil belajar peserta didik dianalisis secara deskriptif dengan mengacu pada ketuntasan belajar secara klasikal. Hasil analisa data observasi aktivitas guru siklus I diperoleh skor rata-rata 28 dengan kriteria baik, pada siklus II meningkat menjadi 32 dengan kriteria baik. Hasil analisa data observasi aktivitas peserta didik siklus I diperoleh rata-rata 27,5 dengan kriteria baik, pada siklus II meningkat menjadi 32 dengan kriteria baik. Hasil analisa hasil belajar peserta didik pada siklus I diperoleh persentase ketuntasan belajar klasikal 75\% dengan kriteria tidak tuntas, pada siklus II mengalami peningkatan menjadi $87,5 \%$ dengan kriteria tuntas. Disimpulkan bahwa model pembelajaran berbasis masalah (PBM) pada materi pencemaran lingkungan dapat meningkatkan aktivitas dan hasil belajar peserta didik di kelas VII ${ }_{G}$ SMPN 10 Kota Bengkulu.
\end{abstract}

Kata kunci:Pembelajaran berbasis masalah, aktivitas, hasil belajar.

\begin{abstract}
This research aimed to describe the activities and learning outcomes of students in class $\mathrm{VII}_{\mathrm{G}} \mathrm{SMPN}$ 10 Kota Bengkulu by using problem-based learning models on environmental pollution material teaching. This type of research is classroom action research (CAR) with descriptive methods. This research consists of two cycles, each cycle consists of four stages, namely planning, implementing, observing, reflecting. The subject of the research was the teacher and all the students of $\mathrm{VII}_{\mathrm{G}} \mathrm{class}_{\text {of }}$ SMPN 10 Kota Bengkulu in the academic year 2017/2018 academic year which was 32 people. The research instrument used was an observation sheet to determine the activity of teachers and students, while the test sheet was used to determine the learning outcomes of students. Student learning outcomes data were analyzed descriptively by referring to the completeness of classical learning. The results of the analysis of teacher activity observation data for cycle I obtained an average score of 28 with good criteria, in the second cycle increased to 32 with good criteria. The results of the analysis of observational data on the activities of students in cycle I were obtained on average 27.5 with good criteria, in cycle II it increased to 32 with good criteria. The results of the analysis of the learning outcomes of students in the first cycle obtained the percentage of classical learning completeness $75 \%$ with criteria not completed, in the second cycle increased to $87.5 \%$ with complete criteria. It was concluded that the problem-based learning models (PBM) on the material of environmental pollution can increase the activity and learning outcomes of students in class $\mathrm{VII}_{\mathrm{G}}$ SMPN 10 Kota Bengkulu.

Keywords: Problem-based learning, activity, learning outcomes.
\end{abstract}




\section{PENDAHULUAN}

Salah satu usaha pemerintah indonesia dalam meningkatkan mutu pendidikan adalah dengan mengaplikasikan kurikulum 2013. Kurikulum 2013 memberikan kebebasan kepada guru untuk membentuk kompetensi peserta didik sesuai dengan kebutuhan dan minat peserta didik(Daryanto, 2014). Kurikulum ini juga menyatakan bahwa keberhasilan proses belajar mengajar tidak hanya ditentukan oleh hasil akhir, tetapi juga oleh proses pembelajaran(Abdullah, 2014).

Tingkat keberhasilan penerapan kurikulum 2013 tergantung pada proses belajar mengajar yang dilakukan oleh peserta didik dan guru. Perubahan cara pandang terhadap peserta didik dari objek menjadi subjek dalam proses pembelajaran menjadi titik tolak ditemukanya berbagai model pembelajaran yang inovatif. Salah satu model pembelajaran yang inovatif adalah model pembelajaran berbasis masalah (PBM)(Trianto, 2014). Melalui model PBM, kegiatan belajar diharapkan dapat memberdayakan peserta didik menjadi individu yang mandiri dan mampu menghadapi setiap permasalahan dalam hidupnya dikemudian hari.

Berdasarkan hasil observasi dan wawancara peneliti dengan guru IPABiologi kelas $\mathrm{VII}_{\mathrm{G}}$ saat magang tahun 2017 di SMP Negeri 10 Kota Bengkulu, diketahui bahwa permasalahan pembelajaran yang dapat diidentifikasi dari kelas $\mathrm{VII}_{\mathrm{G}}$ adalah: 1) Guru jarang menggunakan model pembelajaran interaktif dan lebih sering menggunakan model pembelajaran langsung; 2) Kegiatan pembelajaran lebih didominasi guru; 3) Guru tidak mengaitkan masalah yang ada dikehidupan nyata dengan materi pembelajaran. Kondisi ini mengakibatkan adanya permasalahan pembelajaran pada peserta didik antara lain: 1) Peserta didik kurang aktif dalam proses pembelajaran; 2) Peserta didik menjadikan guru sebagai satu-satunya sumber belajar padahal buku penunjang pembelajaran sudah diberikan; 3) Peserta didik kurang memahami materi yang disajikan. Permasalahan kegiatan pembelajaran ini berpengaruh terhadap hasil belajar yaitu ketuntasan minimal hanya tercapai pada 21 orang dari 32 (65.62\%) peserta didik. Kriteria ketuntasan minimal (KKM) di SMPN 10 Kota Bengkulu adalah $\geq 75$ untuk peserta didik dengan ketuntasan belajar klasikal $\geq 85 \%$.

Berdasarkan hal tersebut di atas, maka peneliti berkolaborasi dengan guru IPABiologi untuk menguji model pembelajaran berbasis masalah terhadap kualitas pembelajaran di kelas VIIg SMPN 10 Kota Bengkulu. Penelitian ini diharapkan dapat memperbaiki proses pembelajaran dan tuntutan ketuntasan pembelajaran minimal dapat dipenuhi

Tujuan penelitian ini adalah: 1) Memperoleh deskripsi aktivitas mengajar guru dan aktivitas belajar peserta didik dalam proses pembelajaran materi Pencemaran Lingkungan dengan menerapkan model pembelajaran berbasis masalah dikelas $\mathrm{VII}_{\mathrm{G}}$ SMPN 10 Kota Bengkulu. 2) Memperoleh deskripsi hasil belajar kognitif peserta didik kelas $\mathrm{VII}_{\mathrm{G}}$ SMPN 10 Kota Bengkulu pada materi pencemaran lingkungan dengan menerapkan model pembelajaran berbasis masalah.

\section{METODOLOGI PENELITIAN}

Jenis penelitian yang digunakan adalah penelitian tindakan kelas (PTK) dengan metode deskriptif. Subyek dalam penelitian tindakan kelas ini adalah peneliti yang sekaligus sebagai guru model dan seluruh peserta didik kelas $\mathrm{VII}_{\mathrm{G}}$ SMPN 10 Kota Bengkulu tahun ajaran 2017/2018 yang berjumlah 32 orang, yang terdiri dari 16 orang laki-laki dan 16 orang perempuan. 
Variabel yang digunakan dalam penelitian ini terdiri dari variabel bebas dan variabel terikat. Variabel bebasnya adalah model Pembelajaran Berbasis Masalah (PBM), sedangkan variabel terikatnya adalah aktivitas mengajar guru, aktivitas belajar peserta didik dan hasil belajar peserta didik kelas $\mathrm{VII}_{G}$ SMPN 10 Kota Bengkulu.

Defenisi operasional terdiri atas : 1) Model PBM merupakan model pembelajaran yang mengaitkan setiap materi dengan masalah yang relevan dikehidupan nyata, 2) Aktivitas guru adalah kegiatan guru dalam mengajar dengan menggunakan model PBM, 3) Aktivitas belajar peserta didik adalah kegiatan peserta didik dalam proses pembelajaran model PBM, 4) Hasil belajar merupakan hasil yang diperoleh peserta didik dari interaksi tindakan pembelajaran.

Teknik pengumpulan data aktivitas guru dan aktivitas peserta didik adalah observasi menggunakan lembar observasi.Teknik yang digunakan untuk mengumpulkan data hasil belajar adalah tes objektif menggunakan lembar tes. Penelitian ini terdiri dari dua siklus yaitu siklus I dan II. Setiap siklus terdiri dari empat tahap yang mengadopsi Kunandar (2013) yaitu: perencanaan, pelaksanan, pengamatan dan refleksi.

Teknik analisis data observasi aktivitas guru dan peserta didik yaitu dengan rerata skor dan penentuan kategori skor berdasarkan kisaran kategori yang ditetapkan yaitu baik, cukup, kurang, menggunakan rumus:

$$
\text { Rerata skor }(\bar{X})=\frac{\sum X}{N}
$$

Keterangan:

$\bar{X}=$ Rata-rata

$\sum X=$ Jumlah skor

$N=$ Jumlah observer

Kategori skor $=\frac{\text { skor tertinggi-skor terendah }}{\text { jumlah kategori }}$

(Arikunto, 2012)
Tabel 1. Kriteria Penilaian Lembar Observasi Aktivitas Guru dan Peserta Didik

\begin{tabular}{ccc}
\hline No & Interval & Kriteria Penilaian \\
\hline 1 & $11.00-18.33$ & Kurang (1) \\
2 & $18.34-25.67$ & Cukup (2) \\
3 & $25.68-33.01$ & Baik (3) \\
\hline
\end{tabular}

Data tes hasil belajar ranah kognitif dianalisa menggunakan rumus sebagai berikut:

1) Rerata hasil belajar

$$
\bar{X}=\frac{\sum X}{N}
$$

Keterangan:

$\overline{\mathrm{X}}=$ Nilai rata-rata

$\sum x=$ jumlah nilai yang diperoleh

$\mathrm{N}$ = jumlah siswa (Arikunto, 2012)

2) Presentase Ketuntasan belajar

Keterangan:

$\mathrm{KB}=$ Ketuntasan Belajar Klasikal

NS =Jumlah peserta didik yang memperoleh nilai $\geq 75$

$\mathrm{N}=$ Jumlah seluruh peserta didik

$$
\text { Ketuntasan Belajar }(\text { KB })=\frac{N S}{N} \times 100 \%
$$

(Trianto, 2012)

\section{HASIL DAN PEMBAHASAN}

Berdasarkan penelitian yang telah dilaksanakan dikelas $\mathrm{VII}_{\mathrm{G}}$ SMPN 10 Kota Bengkulu berupa penerapan model pembelajaran berbasis masalah (PBM) sebanyak 2 siklus pada materi Pencemaran Lingkungan menunjukkan bahwa model PBM dapat meningkatkan aktivitas guru, aktivitas peserta didik dan hasil belajar peserta didik. Hal ini dapat dilihat dari peningkatan skor rata-rata aktivitas guru dan aktivitas peserta didik (Grafik 1), serta peningkatan hasil belajar peserta didik pada (Grafik 2). Peningkatan pembelajaran yang terjadi pada siklus II karena adanya refleksi pada proses pembelajaran disiklus I. Melalui kegiatan refleksi pada siklus I, peneliti dapat memperbaiki proses 
pembelajaran sehingga kualitas dan hasil belajar di siklus II menjadi lebih baik.

\section{A. Aktivitas Guru dan Peserta Didik Melalui Penerapan Model Pembelajaran Berbasis Masalah}

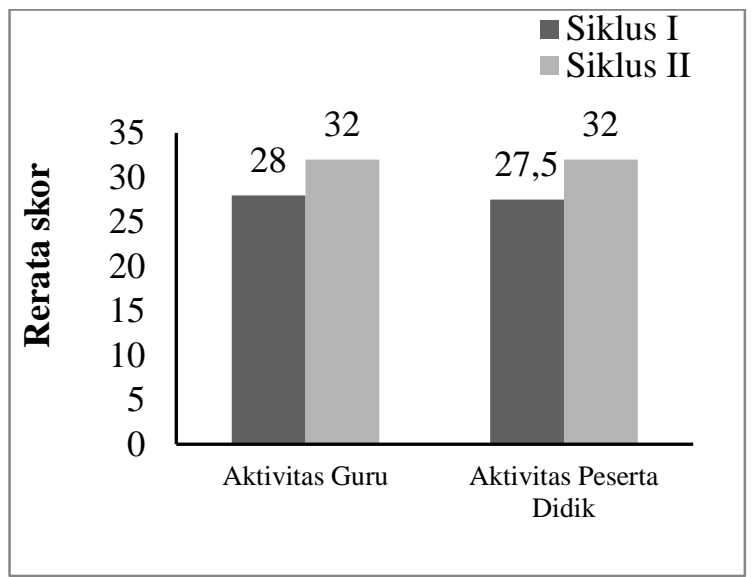

Grafik 1.Rata-rata skor observasi aktivitas guru dan peserta didik antarasiklus I dan II kegiatan pembelajaran berbasis masalah di kelas VIIg SMPN 10Kota Bengkulu.

Grafik 1 menunjukan bahwa rerata skor observasi aktivitas guru pada siklus I adalah 28 meningkat pada siklus II menjadi 32. Skor aktivitas peserta didik juga mengalami peningkatan. Rerata skor observasi aktivitas peserta didik pada siklus I adalah 27,5 meningkat pada siklus II menjadi 32.

Berikut adalah penjabaran dari aktivitas guru dan aktivitas peserta didik berdasarkan sintaks atau tahapan model PBM dalam proses pembelajaran yang telah dilakukan:

\section{Orientasi peserta didik pada masalah}

Pada tahap orientasi peserta didik pada masalah, guru menjelaskan tujuan pembelajaran. Pada aktivitas guru disiklus I kegiatan ini kriteria cukup karena guru hanya menjelaskan tujuan pembelajaran tanpa menulis/menanyangkan melalui media. Hal ini juga mempengaruhi aktivitas peserta didik, yaitu hanya beberapa peserta didik yang mencatat tujuan pembelajaran yang disampaikan guru. Setelah dilakukan refleksi, guru menayangkan tujuan pembelajaran menggunakan power point sehingga aspek ini dinilai baik pada siklus II. Hal ini juga mempengaruhi aktivitas peserta yaitu terlihat seluruh peserta didik memperhatikan dan mencatat tujuan pembelajaran. Menurut Kosasih (2014), menjelaskan tujuan pembelajaran sangat penting dilakukan. Apabila peserta didik sudah mengetahui tujuan pembelajaran, peserta didik akan menjadi lebih terarah dalam proses pembelajaran.

Selain menjelaskan tujuan pembelajaran, pada tahap orientasi peserta didik guru juga mengajukan fenomena untuk memunculkan masalah. Pada siklus I guru mengajukan fenomena berupa gambar tentang perbedaan sungai yang tercemar oleh limbah detergen dan sungai tidak tercemar. Sedangkan pada siklus II guru mengajukan fenomena berupa gambar tentang perbedaan kondisi udara dan tanah pada lingkungan pendesaan dan perkotaan. Gambar tersebut dapat merangsang peserta didik untuk berfikir memunculkan rasa ingin tahu dengan memperhatikan gambar yang ditampilkan oleh guru. Hal ini selaras dengan Anam (2016), bahwa dengan menggunakan gambar dapat merangsang keingintahuan peserta didik terhadap materi yang disampaikan.

Tahap orientasi masalah ditutup dengan kegiatan guru memotivasi peserta didik untuk terlibat dalam pemecahan masalah. Pada aktivitas guru disiklus I dan siklus II tahapan ini dengan kriteria baik karena guru memotivasi seluruh peserta didik dengan mengajukan pertanyaan terkait gambar yang telah ditampilkan. Peserta didik sangat antusias melihat gambar yang ditampilkan dan berebutan menjawab pertanyaan yang diberikan oleh guru. Respon peserta didik seperti ini menunjukkan bahwa peserta didik termotivasi untuk mengetahui bahkan mempelajari lebih dalam mengenai topik pelajaran. Hal ini sesuai dengan yang 
disampaikan oleh Sardiman (2012) bahwa salah satu bentuk aktivitas peserta didik yang menunjukkan termotivasi untuk mempelajari suatu hal adalah dengan menjawab semua pertanyaan yang diberikan tanpa berpikir benar atau tidak jawaban yang diberikannya.

\section{Mengorganisasikan peserta didik}

Pada tahap mengorganisasikan peserta didik yaitu terkait dengan persiapan peserta didik dalam melaksanakan kegiatan dalam kelompok. Kelompok dibentuk oleh guru secara heterogen berdasarkan kemampuan dan jenis kelamin. Pada siklus I peserta didik tampak gaduh ketika anggota kelompok telah ditentukan oleh guru.Peserta didik ingin memilih anggota kelompoknya sendiri dan ada peserta didik yang malas untuk berpindah tempat.Peserta didik masih memerlukan arahan dari guru, sehingga guru harus mengulang-ulang instruksi dalam pembagian kelompok. Menurut Rusman (2014) Salah satu peranan guru dalam belajar yaitu guru berperan sebagai organisator dimana guru mengatur proses jalannya kegiatan pembelajaran dari awal sampai akhir pembelajaran agar kegiatan belajar dapat berjalan dengan baik dan lancar. Setelah dilakukan refleksi pada siklus II sudah berjalan dengan baik, peserta didik terlihat suasana kelas tidak gaduh lagi seperti pada siklus $\mathrm{I}$.

Setelah membagi kelompok, guru kemudian membagikan LKPD/LDPD dan menjelaskan seluruh prosedur kegiatan pembelajaran yang ada di LKPD/LDPD secara sistematis. Seluruh kelompok peserta didik (6 kelompok) memperhatikan saat guru menyampaikan prosedur kegiatan pada LKPD/LDPD disiklus I dan pada LKPD disiklus II, selain itu peserta didik aktif bertanya apabila belummemahami prosedur yang dijelaskan oleh guru.

\section{Membimbing penyelidikan individual dan kelompok}

Pada tahap ini, kegiatan yang dilakukan oleh guru yaitu membimbing seluruh kelompok peserta didik dalam melakukan percobaan/diskusi dalam pemecahan masalah. Pada aktivitas guru disiklus I kegiatan ini dinilai cukup, karena terlihat guru belum mampu membimbing seluruh kelompok dalam melakukan percobaan. Hal tersebut mempengaruhi aktivitas peserta didik yaitu hanya 4 kelompok peserta didik melakukan percobaan/diskusi sesuai prosedur yang ada di LKPD, 2 kelompok lainnya melakukan percobaan tetapi tidak sesuai dengan prosedur yang ada di LKPD.Pada siklus II, aktivitas guru dinilai baik, karena guru sudah mampu membimbing seluruh kelompok (6 kelompok) sehingga peserta didik yang awalnya pasif terlihat bersemangat dan aktif saat diskusi.

\section{Mengembangkan dan menyajikan hasil karya}

Kegiatan yang dilakukan guru pada tahap ini adalah membimbing seluruh kelompok peserta didik dalam menyiapkan hasil karya berupa jawaban dari LKPD/LDPD. Pada siklus I, aktivitas guru dinilai cukup karena guru hanya membimbing 4 kelompok sehingga hanya 4 kelompok peserta didik yang menyiapkan laporan yang sesuai dengan hasil percobaan yang diperoleh. Pada siklus II, kegiatan ini sudah berjalan dengan baik, karena guru sudah mampu membimbing dan mendatangi seluruh kelompok (6 kelompok). Aktivitas peserta didik juga menjadi lebih baik, karena terlihat seluruh kelompok menyiapkan hasil karya sesuai percobaan yang diperoleh dengan tepat waktu.

Selanjutnya pada tahap ini, guru juga meminta perwakilan setiap kelompok presentasi didepan kelas untuk memaparkan hasil percobaan/diskusi. Pada siklus I dan siklus II aktivitas guru dinilai cukup oleh pengamat karena guru hanya meminta 3 kelompok yang 
mempresentasikan hasil karyanya. Beberapa kelompok ada yang belum menyelesaikan tugasnya sesuai dengan waktu yang telah ditetapkan oleh guru.Keterbatasan waktu menyebabkan aktivitas tersebut tidak berjalan dengan efektif. Menurut Gunantara (2014) salah satu kelemahan dari model Pembelajaran Berbasis Masalah yaitu membutuhkan waktu yang tidak sedikit dalam kegiatan pembelajaran, sehingga dibutuhkan kemampuan guru dalam mengelola waktu agar kegiatan pembelajaran dapat berjalan sesuai dengan direncanakan.

\section{Menganalisis dan mengevaluasi proses pemecahan masalah}

Pada tahap ini kegiatan guru adalah membimbing peserta didik untuk melakukan refleksi terhadap materi yang telah diajarkan. Pada siklus I dan siklus II tahap membimbing peserta didik melakukan refleksi terhadap materi yang telah diajarkan dikategorikan baik oleh pengamat, karena guru membimbing seluruh kelompok untuk melakukan refleksi dengan mengulas kembali materi yang telah diajarkan serta mengaitkannya dengan proses percobaan/diskusi.

Selanjutnya untuk mengetahui tingkat keberhasilan peserta didik selama mengikuti pembelajaran dengan menggunakan model PBM, guru memberikan evaluasi berupa postest dalam bentuk tes tertulis. Hal ini sesuai dengan pendapat Wijaya dkk (2015) bahwa evaluasi pembelajaran merupakan sebagai suatu proses menentukan hasil yang telah dicapai dari beberapa kegiatan yang direncanakan untuk mendukung tercapainya suatu tujuan pembelajaran. Pada aktivitas guru siklus I kedua pengamat menilai cukup karena guru memberikan soal postest dengan waktu yang kurang, sehingga mempengaruhi aktivitas peserta didik yang hanya dinilai cukup karena peserta didik mengerjakan soal postest dengan terburu-buru.Setelah dilakukan refleksi, pada siklus II kedua pengamat sudah menilai baik, karena guru memberikan postest tepat waktu.

\section{B. Hasil Belajar Peserta Didik Melalui Penerapan Model Pembelajaran Berbasis Masalah.}

Peningkatan hasil belajar peserta didik dengan menerapkan model pembelajaran berbasis masalah (PBM) dilihat dari meningkatnya hasil postest yang diberikan diakhir pembelajaran.

Pada siklus I rata-rata hasil belajar peserta didik adalah 80,6 meningkat menjadi 85,3 pada siklus II, sehingga persentase ketuntasan klasikal juga meningkat dari $75 \%$ (belum tuntas) pada siklus I menjadi $87,5 \%$ (tuntas) pada siklus II (Grafik 2).

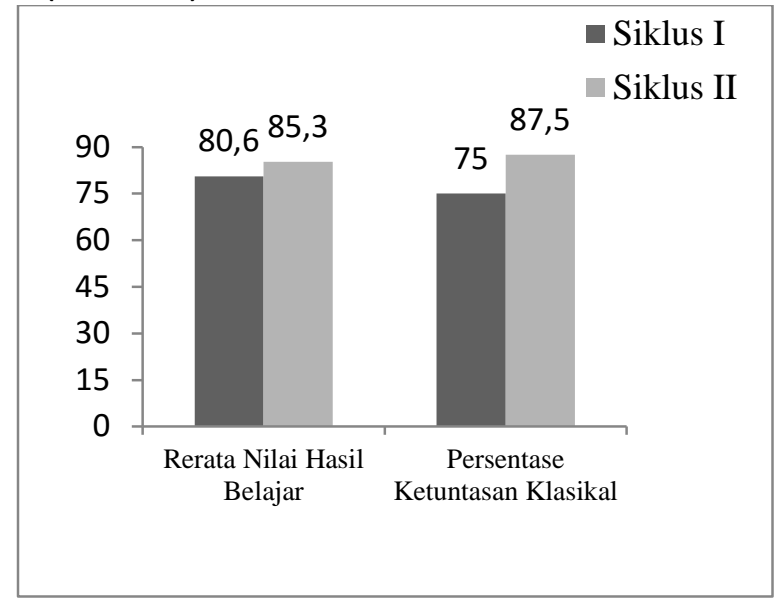

Grafik 2.Peningkatan rerata nilai hasil belajar dan persentase ketuntasan klasikal antara siklus I dan II kegiatan pembelajaran berbasis masalah di kelas VIIg SMPN 10 Kota Bengkulu.

Hasil ini memperkuat penelitian Nanda (2013) di kelasVIII ${ }_{1}$ SMPN 14 Kota Bengkulu menunjukkan bahwa model PBM dapat meningkatkan hasil belajar peserta didik yang dilihat dari ketuntasan belajar klasikal yang diperoleh pada siklus I dengan persentase ketuntasan belajar klasikal 72,22\% (Belum Tuntas) dan terjadi peningkatan disiklus II yaitu 91,67\% (Tuntas). Hasil yang lebih kurang sama didapatkan Surbakti (2014) dikelas VIII d SMPN 6 Kota Bengkulu penerapan model PBM Surbakti (2014) dapat meningkatkan 
hasil belajar peserta didik dilihat dari ketuntasan belajar klasikal yang diperoleh pada siklus I yaitu 65,38\% (Belum tuntas) meningkat pada siklus II menjadi $88,46 \%$ (Tuntas) dan juga penelitian dari Ekananda (2015) di kelas VIIlc SMPN 1 Pondok Kelapapenerapan model PBM Ekananda (2015) dapat meningkatkan hasil belajar peserta didik dilihat dari ketuntasan belajar klasikal yang diperoleh pada siklus I yaitu 73\% (belum tuntas) meningkat pada siklus II menjadi 84,61\% (tuntas).

\section{PENUTUP}

\section{Kesimpulan}

Berdasarkan Penelitian Tindakan Kelas (PTK) dengan menerapkan model Pembelajaran Berbasis Masalah (PBM) yang telah dilakukan dikelas $\mathrm{VII}_{\mathrm{G}}$ SMPN 10 Kota Bengkulu pada materi pencemaran lingkungan, dapat ditarik kesimpulan sebagai berikut:

1. Penerapan model Pembelajaran Berbasis Masalah (PBM) pada materi pencemaran lingkungan dikelas $\mathrm{VII}_{G} \mathrm{SMPN}$ 10 Kota Bengkulu dapat meningkatkan aktivitas mengajar guru dan aktivitas belajar peserta didik. Pada siklus I aktivitas guru diperoleh rerata skor 28 (baik) meningkat pada siklus II menjadi 32 (baik). Sedangkan aktivitas peserta didik pada siklus I diperoleh rerata skor 27,5(baik) meningkat pada siklus II menjadi 32 (baik). 2. Penerapan model pembelajaran berbasis masalah pada materi pencemaran lingkungan di kelas $\mathrm{VII}_{\mathrm{G}}$ SMPN 10 Kota Bengkulu dapat meningkatkan hasil belajar kognitif peserta didik yang dilihat dari ratarata hasil belajar peserta didik pada siklus I yaitu 80,6 meningkat pada siklus II menjadi 85,3 .sehingga persentase ketuntasan klasikal juga meningkat dari $75 \%$ (belum tuntas) pada siklus I menjadi $87,5 \%$ (tuntas) pada siklus II.

\section{Saran}

1. Peneliti hendaknya memperhatikan waktu pada saat berlangsungannya proses pembelajaran agar tahap-tahap pembelajaran dapat terlaksana dengan tepat waktu.

2. Diharapkan kepada peneliti sebaiknya harus lebih memahami sintaks dari model Pembelajaran Berbasis Masalah (PBM), agar setiap kegiatan/proses pembelajaran yang dilakukan dapat berjalan dengan lancar, sehingga mendapatkan hasil yang baik dan sesuai dengan yang diinginkan.

\section{DAFTAR PUSTAKA}

Abdullah, S. R. (2014). Pembelajaran saintifik untuk kurikulum 2013. Jakarta: Bumi Aksara.

A.M.Sardiman. (2012). Interaksi dan Motivasi Belajar Mengajar. Jakarta: Rajawali Pers.

Anam, K, (2016). Pembelajaran Berbasis Inkuiri. Yogyakarta

Arikunto, S. (2012). Dasar-Dasar Evaluasi Pendidikan. Jakarta: PT Bumi Aksara.

Daryanto. (2014). Pendekatan Pembelajaran Saintifik Kurikulum 2013. Yogyakarta: Gava Media.

Ekananda, Febrandi. (2015). Penerapan Model Pembelajaran Berbasis Masalah (Pbm) Untuk Meningkatkan Hasil Belajar Ipa Biologi Pada Siswa Kelas VIIIC SMPN 1 Pondok Kelapa. Skripsi (Tidak diterbitkan).

Gunantara, G., Suarjana, M., \& Riastini, P. N. (2014). Penerapan Model Pembelajaran Problem Based Learning untuk Meningkatkan Kemampuan Pemecahan. Jurnal Mimbar PGSD Universitas Pendidikan Ganesha, 2(1): 1-10.

Kosasih, E. (2014). Strategi Belajar dab Pembelajaran Implementasi Kurikulum 2013. Bandung: Penerbit Yrma Widya. 
Kunandar. (2013). Langkah Mudah Penelitian Tindakan Kelas Sebagai Pengembangan Profesi Guru. Jakarta: PT. Raja Grafindo Persada.

Nanda, J Setia. (2013). Penerapan Model Pembelajaran Berbasis Masalah Untuk Meningkatkan Hasil Belajar Siswa Kelas VIII.1 SMPN 14 Kota Bengkulu. Skripsi (Tidak diterbitkan).

Rusman. (2014). Model-Model Pembelajaran Mengembangkan Profesionalisme Guru (Kedua). Jakarta: Rajawali Pers.

Surbakti, V Hendriyanto, (2014). Penerapan Model Pembelajaran Berbasis Masalah (PBM) Untuk Meningkatkan Hasil Belajar Biologi Siswa Kelas VIIId SMPN 6 Kota Bengkulu. Skripsi (Tidak diterbitkan).

Trianto. (2012). Model Pembelajaran Terpadu. Jakarta: PT Bumi Aksara.

Trianto. (2014). mendesain model pembelajaran inovatif, progresif, dan kontekstual. Jakarta: Kencana Prenada Media Group.

Wijaya, I Wayan, dkk. (2015). Pengaruh Model Pembelajarran Berbasis Masalah Terhadap Hasil Belajar IPA ditinjau dari Minat Siswa Terhadap Pelajaran IPA Pada Siswa SD di Gugus IV Kecamatan Manggis. Jurnal Skripsi, diakses pada tanggal 20 November 2018. 